\title{
Article/Artigo
}

\section{Prevalence of hepatitis $B$ virus infection and carriage after nineteen years of vaccination program in the Western Brazilian Amazon}

\author{
Prevalência da infecção e de portadores do vírus da hepatite B, após 19 anos do programa de \\ vacinação na Amazônia ocidental Brasileira
}

\begin{abstract}
Wornei Silva Miranda Braga ${ }^{1,2}$, Márcia da Costa Castilho ${ }^{1,2}$, Fabiane Giovanella Borges ${ }^{1}$, Ana Cristina de Souza Martinho ${ }^{1}$, Ivo Seixas Rodrigues ${ }^{1}$, Eliete Pereira de Azevedo ${ }^{1}$, Márcia Scazufca ${ }^{3}$ and Paulo Rossi Menezes ${ }^{3}$
\end{abstract}

\begin{abstract}
Introduction: Reductions in the prevalence of hepatitis B virus (HBV) infection and carriage, decreases in liver cancer incidence, and changes in patterns of liver dysfunctions are described after hepatitis B vaccination. Methods: We conducted a population-based seroprevalence study aimed at estimating the $\mathrm{HBV}$ prevalence and risk of infection in the rural area of Lábrea following nineteen years of HBV vaccination. Results: Half of the subjects showed total anti-HBc of 52.1\% (95\% CI 49.6-54.7). The HBsAg prevalence was 6.2\% (95\% CI 5.1-7.6). Multivariate analysis showed an inverse association between $\mathrm{HBV}$ infection and vaccination (OR 0.62 ; 95\% CI 0.44-0.87). HBsAg remained independently associated with past hepatitis (OR 2.44; 95\% CI 1.52-3.89) and inversely to vaccination (OR 0.43; 95\% CI 0.27-0.69). The prevalence of $\mathrm{HBeAg}$ among HBsAg-positive individuals was $20.4 \%$ (95\% CI 12.8-30.1), with the positive subjects having a median age of 11 years $(1-46) \mathrm{p}=0.0003$. Conclusions: We demonstrate that HBV infection is still an important public health issue and that HBV vaccination could have had better impact on $\mathrm{HBV}$ epidemiology. If we extrapolate these findings to other rural areas in the Brazilian Amazon, we can predict that the sources of chronic infected patients remain a challenge. Future studies are needed regarding clinical aspects, molecular epidemiology, surveillance of acute cases, and risk groups.
\end{abstract}

Keywords: HBV. Hepatitis B. Prevalence. Vaccination. Epidemiology.

\section{RESUMO}

Introdução: Reduções nas taxas de prevalência de infecção pelo vírus da hepatite $B$ (VHB) e de portadores, incidência de câncer de fígado e mudança nos padrões de doenças hepáticas são descritos, depois da introdução da vacinação contra hepatite B. Métodos: Foi conduzido um estudo de soro prevalência de base populacional, com o objetivo de estimar a prevalência do VHB e fatores de risco de infecção na área rural de Lábrea, depois de 19 anos de introdução da vacinação contra hepatite B. Resultados: Metade dos indivíduos investigados mostrou reatividade ao anti-HBc total, $52,1 \%$ (IC 95\% 49,6-54,7). A prevalência do $\mathrm{HBsAg}$ foi 6,2\% (IC 95\% 5,1-7,6). Análises multivariadas mostrou associação inversa da infecção pelo VHB e vacinação (OR 0,62; IC 95\% 0<44-0,87). A presença do HBsAg permaneceu independentemente associada com o passado de hepatite (OR 2,44; IC 95\% 1,52-3,89) e inversamente associado a história de vacinação (OR 0,43; IC 95\% 0,27-0,69). A prevalência do HBeAg, entre os HBsAg positivos foi 20,4\% (IC95\% 12,8-30,1), tendo em média os indivíduos positivos 11 anos de idade (1-46) p=0,0003. Conclusões: Foi demonstrado que o VHB é ainda um importante problema de saúde publica, e que a vacinação contra o VHB poderia ter tido um impacto maior na epidemiologia do VHB na região. Se esses achados forem extrapolados para outras regiões rurais da Amazônia brasileira, podemos predizer que a fonte de pacientes crônicos é ainda um desafio a ser vencido. Estudos futuros devem focar os aspectos clínicos, a epidemiologia molecular, vigilância de casos agudos e grupos de risco.

Palavras-chaves: HBV. Hepatite B. Prevalência. Vacinação. Epidemiologia.

1. Gerência de Virologia, Fundação de Medicina Tropical Doutor Heitor Vieira Dourado, Manaus, AM. 2. Programa de Pós-Graduação em Doenças Tropicais e Infecciosas, Universidade do Estado do Amazonas, Manaus, AM. 3. Faculdade de Medicina, Universidadede São Paulo, São Paulo, SP.

Addressto: Dr. Wornei Silva Miranda Braga. Gerência de Virologia/FMT-HVD. Av. Pedro Teixeira 25, Dom Pedro, 69040-00 Manaus, AM, Brasil.

Phone: 5592 2127-3447; Fax: 5592 3238-3762

e-mail:wornei.braga@hotmail.com; wbraga@fmt.am.gov.br

Received in 18/03/2011

Accepted in 03/08/2011

\section{INTRODUCTION}

Hepatitis B virus (HBV) infection has a global public health impact, with some 300 million chronic carriers worldwide ${ }^{1}$. Clinical importance is associated with both fatal acute infection and chronic diseases (chronic hepatitis, liver cirrhosis, and liver cancer).

High prevalence rates have been described in Southeast $\mathrm{Asia}^{2}$, Africa ${ }^{3}$, the Pacific Islands ${ }^{4}$, the Amazon region $^{5-6}$, and Alaska ${ }^{7}$. In these areas, the virus is primarily transmitted perinatally from infected mothers, horizontally in early childhood ${ }^{8-10}$, or by blood exposure as a result of cultural practice ${ }^{11}$.

In the Brazilian Amazon, prevalence rates of $70 \%$ for past infection and $15 \%$ for surface antigen (HBsAg) carriage have been described ${ }^{12}$. Outbreaks of acute fatal hepatitis used to be very common in small rural villages, with a very high case fatality rate associated with hepatitis delta virus (HDV) infection of HBsAg carriers ${ }^{12-13}$.

Reductions in the prevalence of HBsAg infection and carriage, decreases in liver cancer incidence, and even changes in patterns of liver dysfunctions have been described after the implementation of hepatitis $B$ vaccination programs in highly endemic countries $^{14-17}$.

We conducted a population-based crosssectional survey aimed at estimating the HBV serological marker prevalence and risk of infection in the rural zone of Lábrea county, Western Brazilian Amazon, following nineteen years of implementation of a hepatitis B vaccination program in the region.

\section{METHODS}

This is a population-based seroprevalence study of HBV infection. Lábrea is located in the Southwestern Brazilian Amazon (Figure 1), has an estimated rural population of 10,000 , and was the first place in Brazil to receive the hepatitis $B$ vaccine during the first national vaccination campaign in October 1989. 


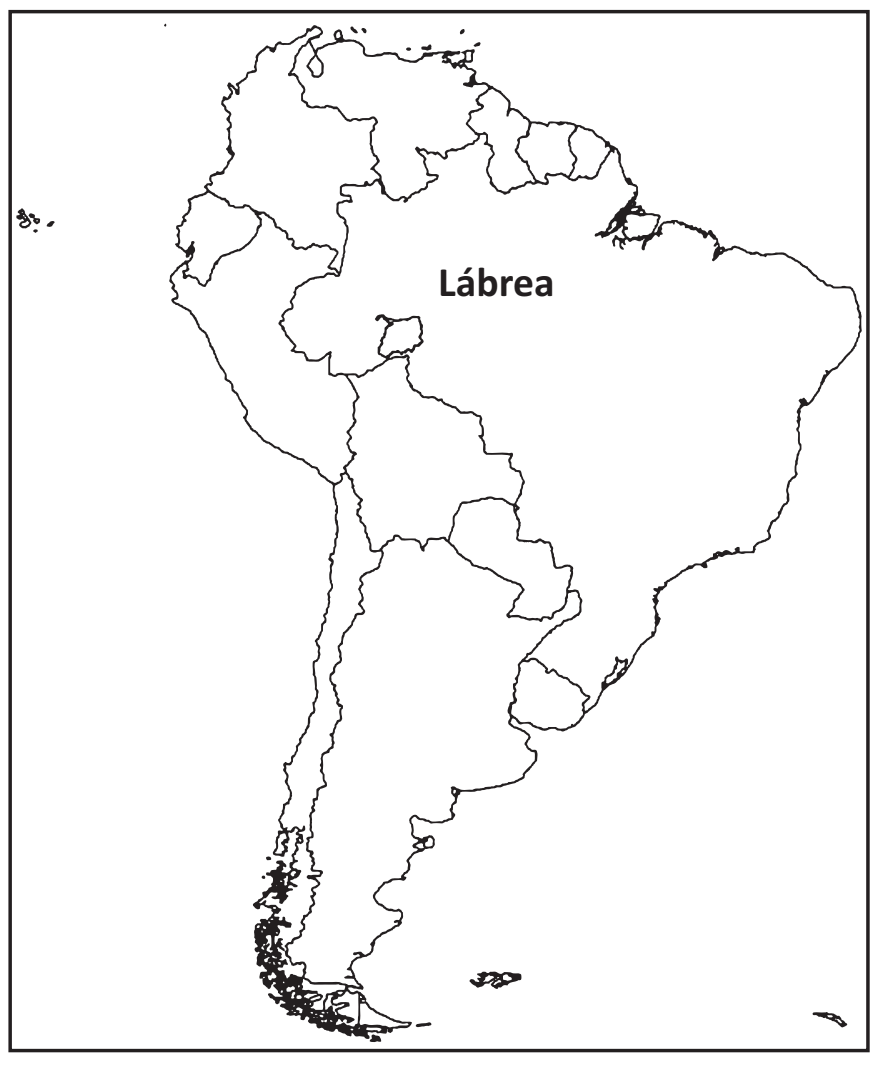

FIGURE 1 - Map of the study area.

The region was first reached during the colonization period by those collecting forest products. In the nineteenth century, during the rubber boom, a huge number of nordestinos, those born in Northeast Brazil, resettled in the area to work at the natural rubber plantations. Currently, the villages are small, formed by those who remained after rubber extraction declined. The economy is still based on the exploitation of natural resources, such as seasonal agriculture at the half-year flooded banks of the Purus River, timber production, growing Brazil nuts, and raising livestock, with the products traded locally. The socioeconomic conditions are very poor, and the annual per capita income is around US $\$ 1,000$.

The target population consisted of all individuals living in the villages that compose the Lábrea County, along the Purus River. Villages were first randomly selected from a list from the Malaria Control Program, assuring that we had covered all the provincial geographical areas along the banks of the Purus River. Then, the research team randomly selected households in each village. The villages were visited from March 2005 to April 2006, during three major twenty-day expeditions and a few one-day trips to the villages near the town of Lábrea.

After signing the formal consent to participate, each individual filled out a questionnaire. A $10 \mathrm{~mL}$ blood sample was taken from each of those present during the investigation; some family members were included later during our stay at the location because they were absent at the time of the visit.

The sample size was estimated using the official rural population census $^{18}$, resulting in an estimated HBsAg prevalence of $6.4 \%{ }^{19}$, a design factor of $2, \pm 2 \%$ precision, and $95 \%$ confidence level, which yielded a minimum sample of 1,009 individuals.

The serum samples were stored at $-20^{\circ} \mathrm{C}$ locally before being flown to Manaus, where they were analyzed by enzyme-linked immunosorbent assay (ELISA). All sera were tested for quantitative anti-HBs and total anti-HBc; those reactive to total anti-HBc and negative for anti-HBs were tested for HBsAg, and those found reactive were tested for $\mathrm{HBeAg}$ and anti-HBe using a commercial kit (DiaSorin S.p.A., Saluggia, Italy). The test procedures followed the manufacturer's recommendations and were performed automatically at the laboratory facilities of the virology unit of Fundação de Medicina Tropical do Amazonas.

Epi Info version $3 \cdot 3.2^{20}$ was used in data handling and sample size calculation; the explanatory variables included gender, age group, vaccination against hepatitis $\mathrm{B}$, and personal antecedent of clinical hepatitis or jaundice. The study population was stratified by two-year groups for the first four years of life, then by 5-year increments up to the age of 19 , and those 20 years or older, which comprised the population at risk of $\mathrm{HBV}$ infection before the implementation of hepatitis $B$ vaccination.

The prevalence rates and corresponding $95 \%$ confidence intervals $(95 \% \mathrm{CI})$ of $\mathrm{HBV}$ infection and carriage were estimated taking into account the study design. Logistic regression was used to calculate the crude ORs and 95\% CIs. A final multiple logistic regression model including all study variables was used to control for confounding using Stata/IC 10.0 ${ }^{21}$.

\section{Ethical considerations}

This study was reviewed and approved by the Research Ethics Committee of the Dr. HeitorVieiraDourado Tropical MedicineFoundation (FMT-HVD), Manaus, Amazonas, Brazil (nº 1775/2006 CEP/FMT).

\section{RESULTS}

This study included 1,510 individuals from 298 families selected in 54 visited villages. The infection and carriage rates varied significantly between villages, from as low as $0 \%$ in Realeza (07035'52.8”S/66 13'29.2”O) to as high as $37.2 \%$ in Madeirinho (07034'19.1”S/65'26'31.4”O).

Nevertheless, with regard to HBsAg prevalence, the great majority of the villages with positive subjects showed rates varying from high to moderate endemic patterns, as shown by the prevalence rates of $10.7 \%$ in Limeira (07043'13.4”S/66 42'33.7”W) and 6.5\% in Praia do Buraco (07017'48.6”'S/6458'28.3”W).

Half of the sample (52.1\%) showed serological markers of past HBV infection (95\% CI 49.6-54.7). HBV infection was strongly associated with increasing age (Chi-square for linear trend $=551.28$, $\mathrm{p}<0.001)$ and positively associated with past history of clinical hepatitis (OR2.31(95\% CI 1.74-3.06) $\mathrm{p}<0.001)$; it was also inversely related to HBV vaccination (OR 0.33 (95\% CI 0.25-0.43) p<0.001) (Table 1).

The current infection (HBsAg+) prevalence was 6.2\% (95\% CI 5.1-7.6) and also increased significantly with age (Chi-square for linear trend $=48.21, \mathrm{p}<0.001$ ). HBsAg had been present since very early ages, with $2 \%$ of those aged up to four years testing positive. However, the rates reached moderate patterns among adolescents $(5.6 \%, 95 \%$ CI 4.31-6.89) and were as high as $10 \%$ (95\% CI 9.34-10.9) within the cohort of those aged 20 years or more (Table 2).

HBV current infection also showed a positive statistical association with past history of clinical hepatitis (OR 3.17 (95\% CI 2.04-4.90) $\mathrm{p}<0.001)$ and was inversely related to HBV vaccination (OR 0.33 (95\% CI 0.21-0.56) $\mathrm{p}<0.001$ ) (Table 2). 
TABLE 1 - Hepatitis B infection (anti-HBc reactive) prevalence and associated variables, Rural Lábrea municipality, Western Amazon, Brazil, 2007.

\begin{tabular}{|c|c|c|c|c|c|c|c|c|}
\hline \multirow[b]{2}{*}{ Variable } & \multirow{2}{*}{$\begin{array}{c}\text { Subjects } \\
\text { (n) }\end{array}$} & \multicolumn{3}{|c|}{ Positive subjects } & \multirow[b]{2}{*}{ Crude OR $(95 \% \mathrm{CI})$} & \multirow[b]{2}{*}{ p-value } & \multirow{2}{*}{$\begin{array}{c}\text { Adjusted } \\
\text { OR }(95 \% \mathrm{CI})^{*}\end{array}$} & \multirow[b]{2}{*}{ p-value } \\
\hline & & $\mathbf{n}$ & $\%$ & $(95 \% \mathrm{CI})$ & & & & \\
\hline Total sample & 1,510 & 787 & 52.1 & $(49.6-54.7)$ & - & - & - & - \\
\hline \multicolumn{9}{|l|}{ Age group } \\
\hline$\leq 2$ & 136 & 24 & 17.6 & $(16.1-19.1)$ & 1 & & 1 & $<0.001^{* *}$ \\
\hline $3-4$ & 114 & 14 & 12.3 & $(10.8-14.0)$ & $0.65(0.32-1.33)$ & 0,24 & $0.73(0.36-1.52)$ & \\
\hline $5-9$ & 298 & 55 & 19.8 & $(18.8-20.8)$ & $1.15(0.68-1.94)$ & 0,59 & $1.23(0.72-2.12)$ & \\
\hline $10-14$ & 216 & 84 & 38.9 & $(37.9-39.9)$ & $2.97(1.77-4.99)$ & $<0,0001$ & $3.11(1.81-5.30)$ & \\
\hline $15-19$ & 143 & 71 & 49.7 & $(48.5-50.9)$ & $4.60(2.66-7.97)$ & $<0,0001$ & $4.16(2.35-7.35)$ & \\
\hline$\geq 20$ & 603 & 535 & 88.7 & $(88.4-88.9)$ & $36.7(22.1-61.0)$ & $<0,0001$ & $33.6(19.9-57.6)$ & \\
\hline \multicolumn{9}{|l|}{ Gender } \\
\hline female & 749 & 389 & 51.9 & $(51.4-52.4)$ & 1 & & 1 & 0.87 \\
\hline male & 761 & 398 & 52.3 & $(51.8-52.8)$ & $1.01(0.82-1.24)$ & 0.88 & $0.98(0.75-1.27)$ & \\
\hline \multicolumn{9}{|l|}{ Past hepatitis } \\
\hline no & 1,184 & 587 & 49.6 & $(48.6-50.6)$ & 1 & & 1 & \\
\hline yes & 268 & 186 & 69.4 & $(68.7-70.1)$ & $2.31(1.74-3.06)$ & $<0.001$ & $1.06(0.75-1.49)$ & 0.74 \\
\hline \multicolumn{9}{|l|}{ Hep B vaccine } \\
\hline no & 343 & 248 & 72.3 & $(71.7-72.9)$ & 1 & & 1 & 0.005 \\
\hline yes & 1,113 & 514 & 46.2 & $(45.8-46.6)$ & $0.33(0.25-0.43)$ & $<0.001$ & $0.62(0.44-0.87)$ & \\
\hline
\end{tabular}

Anti-HBC: antibody against hepatitis B core antigen; n: number; \%: percentage; 95\% CI: 95\% confidence interval; Hep B vaccine: hepatitis B vaccine.

${ }^{*}$ Adjusted for the variables in Table 1 ; p-value: statistical significance; ${ }^{* *}$ Chi-square for linear trend; OR: odds ratio.

TABLE 2 - Hepatitis B surface antigen (HBsAg reactive) prevalence and associated variables, Rural Lábrea municipality, Western Amazon, Brazil, 2007.

\begin{tabular}{|c|c|c|c|c|c|c|c|c|}
\hline \multirow[b]{2}{*}{ Variable } & \multirow{2}{*}{$\begin{array}{c}\text { Subjects } \\
\text { (n) }\end{array}$} & \multicolumn{3}{|c|}{ Positive subjects } & \multirow[b]{2}{*}{ Crude OR (95\% CI) } & \multirow[b]{2}{*}{ p-value } & \multirow{2}{*}{$\begin{array}{c}\text { Adjusted } \\
\text { OR }(95 \% \mathrm{CI})^{*}\end{array}$} & \multirow[b]{2}{*}{ p-value } \\
\hline & & $\mathbf{n}$ & $\%$ & $95 \% \mathrm{CI}$ & & & & \\
\hline Total sample & 1,510 & 94 & 6.2 & $(5.2-7.6)$ & - & - & - & - \\
\hline \multicolumn{9}{|l|}{ Age group } \\
\hline$\leq 2$ & 136 & 3 & 2.2 & $(0.54-3.86)$ & 1 & & 1 & \\
\hline $3-4$ & 114 & 1 & 0.9 & $(-0.92-2.72)$ & $0.39(0.40-3.82)$ & 0,42 & $0.47(0.48-4.62)$ & $<0.001^{* *}$ \\
\hline $5-9$ & 298 & 12 & 4.0 & $(2.89-5.11)$ & $1.86(0.51-6.70)$ & 0,34 & $1.83(0.50-6.66)$ & \\
\hline $10-14$ & 216 & 12 & 5.6 & $(4.31-6.89)$ & $2.60(0.72-9.41)$ & 0,14 & $2.35(0.64-8.61)$ & \\
\hline $15-19$ & 143 & 5 & 3.5 & $(2.49-4.51)$ & $1.60(0.37-6.84)$ & 0,52 & $1.21(0.28-5.25)$ & \\
\hline$\geq 20$ & 603 & 61 & 10.1 & $(9.34-10.9)$ & $4.98(1.54-16.14)$ & 0,007 & $2.88(0.87-9.55)$ & \\
\hline \multicolumn{9}{|l|}{ Gender } \\
\hline female & 749 & 49 & 6.5 & $(5.8-7.2)$ & 1 & & 1 & \\
\hline male & 761 & 45 & 5.9 & $(5.2-6.6)$ & $0.89(0.59-1.36)$ & 0,61 & $0.81(0.52-1.25)$ & 0.35 \\
\hline \multicolumn{9}{|l|}{ Past hepatitis } \\
\hline no & 1,184 & 37 & 4.8 & $(4.3-5.4)$ & 1 & & 1 & \\
\hline yes & 268 & 37 & 13.8 & $(12.7-14.9)$ & $3.17(2.04-4.90)$ & $<0.001$ & $2.44(1.52-3.89)$ & $<0.001$ \\
\hline \multicolumn{9}{|l|}{ Hep B vaccine } \\
\hline no & 343 & 41 & 12.0 & $(11.0-13.0)$ & 1 & & 1 & \\
\hline yes & 1,113 & 49 & 4.4 & $(3.8-4.9)$ & $0.33(0.21-0.56)$ & $<0.001$ & $0.43(0.27-0.69)$ & $<0.001$ \\
\hline
\end{tabular}

HBsAg: hepatitis B surface antigen; n: number; \%: percentage; 95\% CI: 95\% confidence interval; Hep B vaccine: hepatitis B vaccine.

${ }^{*}$ Adjusted odds ratio for the variables in Table 2; p-value: statistical significance; ${ }^{* *}$ Chi-square for linear trend; OR: odds ratio.

After fitting a multiple logistic regression model including all the study variables, the association of $\mathrm{HBV}$ infection with past history of clinical hepatitis disappeared (OR 1.06 (95\% CI 0.75-1.49) $\mathrm{p}=0.74)$. Nevertheless, we still detected an inverse association with HBV vaccination (OR 0.62 (95\% CI 0.44-0.87) p=0.005) (Table 1).

Hepatitis B virus carriage remained independently associated with past history of hepatitis (OR 2.44 (95\% CI 1.52-3.89) p<0.001) and inversely related to $\mathrm{HBV}$ vaccination (OR 0.43 (95\% CI 0.27-0.69) $\mathrm{p}<0.001$ ) (Table 2).
The prevalence of $\mathrm{HBeAg}$ among $\mathrm{HBsAg}$-positive individuals was $20.4 \%$ (19/93) (95\% CI 12.8-30.1), with the positive subjects having a median age of 11 years $(1-46)(\mathrm{p}=0.0003)$ (Kruskal-Wallis test).

\section{DISCUSSION}

To the best of our knowledge, this is the first population-based seroprevalence study of HBV infection in the rural areas of the Western Brazilian Amazon, within the defined geographical limits, 
conducted after the introduction of an immunization program, which allowed us to measure the impact of $\mathrm{HBV}$ vaccination in this single region.

We examined the HBV prevalence, taking into account the presence of two specific serological markers. Because the presence of total antibodies against the core antigen (total anti-HBc) is a marker of past infection, it can measure the importance of the circulation of the virus but lacks the strength for inferences concerning clinical aspects and transmission. Nevertheless, the presence of HBsAg can identify the transmission scenario and potentially chronically ill individuals.

While studies worldwide have found important drops in the rates of past $\mathrm{HBV}$ infection, as shown by a study in the Colombian Amazon, where less than $10 \%$ of the population aged 5-9 years and around $25 \%$ of those 10 to 14 years showed positive, representing a reduction of 72 and $62 \%$, respectively, after the introduction of the vaccine $^{22}$. In contrast, our study described much higher figures among the same age groups: $19.8 \%$ and $38.9 \%$, respectively. In addition, we reported rates close to $50 \%$ in a group of individuals who should have been immunized after these nineteen years; that is, those aged 15 to 19 years, who belonged to the target population in the first five years of the introduction of the vaccine in the community.

Considering the rates of past infection reported before the introduction of the vaccine, which showed important variations (for example, from 15 to $32 \%$ for those up to five years old $)^{23-24}$, the rate of less than 15\% among those 3-4 years old reported in the present study suggests some impact of the vaccination program on new infections, especially among younger people. Still, we must be cautious with any conclusions because the majority of previous studies done in this region before the introduction of the $\mathrm{HBV}$ vaccine were analyses of non-probabilistic samples.

Our study was able to demonstrate that there has been an important circulation of the virus since very young ages among individuals who should have already been fully immunized. However, we may also stress the fact that the distribution of past infection was heterogeneous among the studied villages and that, in some villages, the whole studied population showed no contact with HBV.

Given that this heterogeneous pattern within villages has been described since the late $1960 \mathrm{~s}^{5-6}, \mathrm{HBV}$ vaccination might have had little impact in changing the HBV epidemiology, which seems to have maintained its historical pattern. We believe that genetic factors ${ }^{25}$ and the vaccination program strategies' failure to focus on risk groups may possibly explain some of these differences since the environmental and social economic conditions are very similar.

Unlike many other publications from former highly endemic countries describing a dramatic drop in the prevalence of HBV carriage after the introduction of the $\mathrm{HBV}$ vaccine in their national immunization programs ${ }^{17,26-28}$, we report an overall prevalence of HBV carriage identified only in highly endemic areas, possibly with no counterpart in the literature thus far in the post-vaccination era.

Chronic carriers were found in all age groups. Indeed, we were able to distinguish three different cohorts with indications of important transmission intensity among those who theoretically should be protected. Infection among those aged up to two years supports the possibility of vertical transmission, while the prevalence among children aged between three and ten years indicates potential horizontal transmission among young groups; within adolescents and young adults up to 19 years, it is possible that infection is due to sexual transmission. Since the virus circulates in all ages, the transmission is dependent on the type of risk factor present in each age cohort.

The prevalence and age distribution of HBeAg support the idea of important transmission among early ages because the presence of this serological marker indicates new infections, high viral load, and potential infectivity ${ }^{29}$.

Taking into account that the prevalence of HBsAg carriage reported in this region before the introduction of the vaccine $e^{13,24}$ varied from $7 \%$ and $12 \%$, there has been very little change in the epidemiological pattern of HBV distribution in this specific region from a hyperendemic situation to a highly to moderately endemic pattern. This is in contrast to the situation in Italy, where the prevalence of HBsAg dropped from $13 \%$ to less than $1 \%$ after twenty years of universal vaccination ${ }^{26}$, and in Taiwan, which expected an overall prevalence rate of HBsAg carriage of less than $0.01 \%$ in the year 2010 27. In the Colombian Amazon, the prevalence of HBsAg carriage among those 5-9 years old dropped from 9\% to $2 \%$, indicating a reduction of more than $70 \%$ after eight years of HBV vaccination $^{22}$.

We do not need to go too far to find better results of the HVB vaccination program in an Amazonian community. A study done in the year 2000 in the urban area of Lábrea not only demonstrated a low prevalence of $\mathrm{HBV}$ carriage among those born in the urban area and no carriers before adolescence but also suggested that the real problem with HBV infection would be in rural sites ${ }^{19}$.

Risk factors such as increasing age and past history of clinical hepatitis were strong predictors of HBV carriage even after those nineteen years, suggesting once again that the $\mathrm{HBV}$ vaccination program may have had little impact in changing the HBV epidemiology and on the aetiology of acute and chronic hepatitis in this region. Nevertheless, the hepatitis B vaccine has been shown to be an important protection against $\mathrm{HBV}$, with those vaccinated having almost half the risk of infection and carriage of those not vaccinated, reinforcing the notion that the high figures we are describing may be related to a failure to deliver the vaccine to the population at risk.

In conclusion, our study demonstrates that $\mathrm{HBV}$ continues to be an important public health issue in the Amazon region and that the implementation of the $\mathrm{HBV}$ vaccination program in the rural area of Lábrea should have had a much stronger impact on HBV infection and carriage, as observed elsewhere. Vaccination strategies should focus on specific risk groups, such as infants born to a HBsAg-positive mother and adolescents. It seems that those who escape the vaccine intervention are responsible for keeping the prevalence rates of $\mathrm{HBV}$ infection and carriage among the highest still reported.

Hepatitis B vaccination programs are basically implemented to reduce $\mathrm{HBsAg}$ carriage because this marker of current infection is strongly correlated to chronic liver diseases, such as cirrhosis and liver cancer. The Amazonian environment may present operational difficulties for the delivery of any vaccine, mainly because of scarcity of resources and inadequate infrastructure. If we can extrapolate these findings to other rural areas in the Brazilian Western Amazon, we can predict that the sources of chronic infected patients remain a challenge. Future studies are needed regarding clinical aspects, molecular epidemiology, and surveillance of acute cases. 


\section{ACKNOWLEDGMENTS}

We would like to express our gratitude to the municipality of Lábrea, especially to Mayor Gean Barros and the people in the villages we visited, for the very warm welcome and willingness to participate.

\section{CONFLICT OF INTEREST}

The authors declare that there is no conflict of interest.

\section{FINANCIAL SUPPORT}

This work was financially supported by the Fundação de Amparo à Pesquisa do Estado do Amazonas (FAPEAM).

\section{REFERENCES}

1. World Health Organization. Hepatitis B. Fact sheet no. 204. Geneva, Switzerland: World Health Organization; 2000; [cited 2011 May 5 ]. Available from: http:// www.who.int/mediacentre/factsheets/fs204/en/index.html.

2. Hipgrave DB, Nguyen TU, Hoang TL, Do TD, Tran NT, Jolley D, et al. Hepatitis $B$ infection in rural Vietnam and implications for a national program of infant immunization. Am J Trop Hyg 2003; 69:288-294.

3. Kiire CF. The epidemiology and prophylaxis of Hepatitis B in sub-Saharan Africa: a view from tropical and sub-tropical areas. Gut 1996; 38:S5-12.

4. Vogt TM, Goldstein ST, Kuartei S. Endemic hepatitis B virus infection and chronic liver disease mortality in the republic of Palau, 1990-2002. Trans R Soc Trop Med Hyg 2006; 100:1130-1134.

5. Bensabath G, Hadler SC, Pereira Soares MC, Fields H, Dias LB, Popper H, et al.Hepatitis Delta virus infection and Lábrea hepatitis. Prevalence and role in fulminant hepatitis in the Amazon basin. JAMA 1987; 258:479-483

6. Fonseca JFC, Simonetti SRR, Schatzmayr HG, Castejón MJ, Cesário ALO, Simonetti JP. Prevalence of infection with hepatitis delta virus (HDV) among carriers of hepatitis B surface antigen in Amazon State, Brazil. Trans R Soc Trop Med Hyg1988; 82:469-471.

7. Mac Mahon BJ, Schoemberg S, Blkow L, Wainwright RB, Fitzerald MA, Parkinson AJ, et al. Seroprevalence of hepatitis B viral markers in 52,000 Alaska natives. Am J Epidemiol 1993; 138:544-549.

8. Vardas E, Mathai M, Blaau D, McAnerney J, Coppin A, Sim J. Preimmunisation epidemiology of hepatitis B virus infection in South African children.J Med Virol 1999; 58:111-115.

9. Chang MH. Natural history of hepatitis B virus infection in children. J Gastroenterol Hepatol 2000; 15:E16-19.

10. Brasil LM, Fonseca JC, Souza RB, Braga WS, Toledo LM. Prevalência de marcadores para o vírus da hepatite $\mathrm{B}$ em contatos domiciliares no Estado do Amazonas. Rev Soc Bras Med Trop 2003; 36:565-570.

11. Brabin L, Brabin BJ. Cultural factors and transmission of hepatitis B virus. Am J Epidemiol 1985; 122:725-730.

12. Bensabath G, Boshel J. Presença do antígeno "Austrália" (Ag) em populações do interior do Estado do Amazonas-Brasil. Rev Inst Med Trop Sao Paulo 1973 ; $15: 284-288$

13. Hadler SC, Monzon M, Ponzetto A, Anzola E, Rivero D, Mondolfi A, et al. Delta virus infection and severe hepatitis. An epidemic in the Yucpa Indians of Venezuela. Ann Intern Med 1984; 100:339-344.

14. Chang MH, Chen CJ, Lai MS, Hsu HM, Wu TC, Kong MS, et al. Universal hepatitis $B$ vaccination in Taiwan and the incidence of hepatocellular carcinoma in children. Taiwan Childhood Hepatoma Study Group. N Engl J Med1997; 336:1855-1859.

15. Harpaz R, McMahon BJ, Margolis HS, Shapiro CN, Havron D, Carpenter G, et al. Elimination of new chronic hepatitis B virus infections: Results of the Alaska immunization program. J Infect Dis 2000; 181:413-418.

16. Ni YH, Chang MH, Huang LM, Chen HL, Hsu HY, Chiu TY, et al. Hepatitis B virus infection in children and adolescents in a hyperendemic area: 15 years after mass hepatitis B vaccination Ann Intern Med 2001; 135:796-800.
17. Zanetti AR, Van Damme P, Shouval D. The global impact of vaccination against hepatitis B: A historical overview. Vaccine 2008; 26:6266-6273.

18. Instituto Brasileiro de Geografia e Estatística.Database of information by census tract; 2000; [cited 2011 May 5]. Available from: http://www.ibge.gov.br/ cidadesat/default.php/.

19. Braga WSM, Brasil LM, Souza RAB, Melo MS, Rosas MDG, Castilho MC, et al. Prevalência da infecção pelos vírus da hepatite B (VHB) e da hepatite D (VHD) em Lábrea, Rio Purus, Estado do Amazonas. Epidemiol Serv Saude 2004; 13:35-46.

20. Centers for Diesease Control and Prevention. Epi Info ${ }^{\mathrm{TM}}$ statistical software[computer programm].Version 3.3.2. Atlanta GA: Centers for Diesease Control and Prevention; 2005.

21. Statacorp. Stata Statistical software. [computer programm]. Release IC 10.0 College Station, TX: Statacorp; 2006.

22. Hoz F, Perez L, Neira M, Hall AJ. Eight years of hepatitis B vaccination in Colombia with a recombinant vaccine: factors influencing hepatitis B infection and effectiveness. Int J Infect Dis 2008;12:183-189.

23. Alecrim WD, Marreiros LS, Alecrim MGC, Miranda-Santos IKF. Inquérito sobre presença de HBsAg em habitantes de Lábrea-Amazonas. Rev Soc Bras Med Trop $1986 ; 19: 58-59$

24. Bensabath G, Hadler SC, Soares MCP, Fields H, Dias LB, Popper H, et al Epidemiologic and serologic studies of acute viral hepatitis in Brazil's Amazon Basin. Bull Pan Am Health Organ 1987; 21:16-27.

25. Sullivan JS, Hanna JN. A genetic marker associated with non-response to recombinant hepatitis B vaccine by indigenous Australian children. J Paediatr Child Health 1999; 35:412-413.

26. Villa G, Romano L, Sepe A, Lorio R, Paribello N, Zappa A, et al.Impact of hepatitis $\mathrm{B}$ vaccination in a highly endemic area of south Italy and long-term duration of anti-HBs antibody in two cohorts of vaccinated individuals. Vaccine 2007;25:3133-3136.

27. Chen CC, Yen CH, Wu WY, Hu SW, Chen SC, Bell WR, et al.Epidemiology of hepatitis B virus infection among young adults in Taiwan, China after public vaccination program. Chin Med J 2007;120:1155-1158.

28. Tsebe KV, Burnett RJ, Hlungwani NP, Sibara MM, Venter PA, Mphahlele MJ. The first five years of universal hepatitis B vaccination in South Africa: evidence for elimination of HBsAg carriage in under 5-year-olds. Vaccine 2001; 19:3919-3926.

29. Scotto J, Hadchouel M, Hery C, Yvart J, Tiollais P, Brechot C. Detection of hepatitis B virus DNA in serum by a simple spot hybridization technique: comparison with results for other viral markers. Hepatology1983; 3:279-284. 